\title{
Do Childhood Conduct Problems Predict Negative Outcomes in Adolescence? A Longitudinal Analysis
}

\author{
Hepsi Swarna, Philip S.J. Leonard and Weiqiu Yu
}

\begin{abstract}
The primary purpose of this study was to conduct a prospective examination of the relationship between childhood conduct problems and five outcomes in adolescencenamely, Physically violent offenses; Non-violent offenses; Deviant lifestyle; Consumption of tobacco, cannabis, or alcohol; and Meeting the symptom count diagnostic criteria for Conduct Disorder (CD) - while controlling for a series of sociodemographic factors, family characteristics and adolescent experiences. Logistic regression analyses were used to determine if childhood conduct problems in the Canadian National Longitudinal Survey of Children and Youth (NLSCY) Cycle 1 contributed to negative outcomes in adolescence in NLSCY Cycle 4. This was a prospective, population-based study of 3,725 adolescents (12-15 years old) in the NLSCY Cycle 4 (2000-2001) who were 6-9 years old in NLSCY Cycle 1 (1994-95). Childhood conduct problems were found to be associated with Non-violent offenses and Consumption of tobacco, cannabis, or alcohol in adolescence, but they were not found to be associated with Physically violent offenses or Deviant lifestyle in adolescence. Furthermore, children with conduct problems before the age of 10 were more likely to meet the symptom count diagnostic criteria for CD in adolescence.
\end{abstract}

Keywords: DSM-5, conduct problems, subclinical conduct problems, conduct disorder, childhood and adolescence, delinquency, prognosis, attention-deficit hyperactivity disorder

Hepsi Swarna is a Senior Research Assistant at the University of Missouri Kansas City, USA. Her research interests include community-based research, child mental health, health equity and program evaluation. She wrote the paper "Do Childhood Conduct Problems Predict Negative Outcomes in Adolescence?" as part of her Master's thesis at the University of New Brunswick, Canada.

Philip Leonard is an Honourary Research Associate at the University of New Brunswick Department of Economics, where he previously worked for six years. His research interests include education economics, 
health economics, and program evaluation. He is best known for his research on school nutrition policies. $\mathrm{He}$ is currently living and working in Uganda where he is the Country Director for an economic consulting company. Recent publications include: Leonard PSJ, Crouse DL, Boudreau JG, Gupta N and JT McDonald. 2020. "Provider volume and maternal complications after Caesarean Section: Results from a populationbased study" BMC Pregnancy and Childbirth, 20 (37) DOI 10.1186/s12884-019-2709-5; Leonard, Philip S.J. 2017. "Do School Junk Food Bans Improve Student Health? Evidence from Canada" Canadian Public Policy, 43 (2), 105-119. DOI: 10.3138/cpp.2016-090; and Leonard, Philip, S.J. 2015. "Choice of Ontario High Schools and Student Sorting by Ability," Applied Economics, 47 (49), 5282-5302. DOI:10.1080/00036846.2015.1047087.

Weiqiu Yu is a Professor of Economics at the University of New Brunswick Department of Economics. Her research interests include health economics, applied econometric analysis, public policy, and program evaluation. She has published in Public Finance, the Canadian Journal of Economics, Canadian Tax Journal, and Canadian Public Policy. Recent publications include: Yu, Junhan and Weiqiu Yu, 2021 "The Impact of Housing Prices on Birth Rates in China" Journal of Applied Business and Economics Vol. 23(6), 10-20 and Ma, Liang and Weiqiu Yu, 2018 "The Impact of Regional Age Structure on Entrepreneurship in Canada", International Journal of Economics and Business Perspectives, Vol 13(1).

\section{Acknowledgements}

Swarna acknowledges financial support from the Maritime SPOR Support Unit (MSSU) during her studies at the University of New Brunswick (UNB). The MSSU receives financial support from the Canadian Institute of Health Research (CIHR), the Nova Scotia Health Research Foundation, and the New Brunswick Health Research Foundation. The analysis presented in this article was conducted at the New Brunswick Research Data Centre (NB-RDC), which is part of the Canadian Research Data Centre Network (CRDCN). The services and activities provided by the CRDCN are made possible by the financial or in-kind support of the Social Sciences and Humanities Research Council, the CIHR, the Canadian Foundation for Innovation, Statistics Canada and UNB. The views expressed in the article are those of the authors and do not necessarily reflect those of the CRDCN, the MSSU or the funding sources. No endorsement by these parties is intended or should be inferred.

\section{Data Availability Statement}

The data used in this study are from the National Longitudinal Survey of Youth and Children (NLSCY), which is available to researchers at Canadian universities through application to the Canada Research Data Centre Network (https://crdcn.org/). 


\section{Introduction}

Conduct problems associated with conduct disorder (CD), such as aggression, destructive behavior, deceitfulness, and rule-breaking, are among the most common behavioral problems in childhood and adolescence (Frick, 2016; López-Romero, Romero, \& Andershed, 2014). Conduct problems refer to a repetitive and persistent pattern of behavior that violates the basic rights of others or major age-appropriate norms or rules (American Psychiatric Association, 2013). Studies have found that youth who exhibit symptoms of CD in childhood stand at an increased risk for exhibiting protracted criminal behavior (Pardini, Byrd, Hawes, \& Docherty, 2018). In the area of adolescent antisocial behavior research, conduct problems before the age of 10 have been found to be associated with conduct problems in adolescence that persist through adolescence (Conduct Problems Prevention Research Group, 2010, Loeber \& Farrington, 2001; Loeber, Wei, Stouthamer-Loeber, Huizinga, \& Thornberry, 1999). Research has also established that children with childhood conduct problems are at risk of developing a wide range of adverse outcomes over the life course including adolescence (Frick, 2016, Herrenkohl et al., 2010). These outcomes may include substance abuse, academic problems, criminality, mental health problems and suicidal behaviors (Goldstein, Grant, Ruan, Smith, \& Saha, 2006; Furlong et al., 2012; Kassing, Godwin, Lochman, \& Coie, 2018; National Academies of Sciences, Engineering, and Medicine [NASEM], 2015; Odgers et al., 2007).

Although childhood conduct problems appear to be associated with a number of subsequent problems, the generalizability of past research efforts is somewhat limited (Lichtenstein et al., 2020). First, most past studies were based on comparatively smaller sample size including two birth cohorts in New Zealand ( $\mathrm{N}=1,265$ and 1,037 respectively) (Lichtenstein et al., 2020). Second, few longitudinal studies have explored the adolescent outcomes of children who had conduct problems before age 10 years. Third, most evidence on the outcomes of childhood conduct problems has largely come from clinical or high-risk samples from disadvantaged populations, which included severe cases, while some studies focused only on boys (Lahey et al., 1999; Lahey, Loeber, Burke \& Rathouz, 2002; McCabe, Hough, Wood, \& Yeh, 2001; Moffitt, Caspi, Harrington, \& Milne, 2002; Patterson, Capaldi, \& Bank, 1991). Moreover, these studies focused only on children with a diagnosis of $\mathrm{CD}$ and not on children with subclinical conduct problems (i.e., i.e., conduct problems exhibiting one or two symptoms). It is important not to overlook children younger than the age of 10 with subclinical conduct problems (SCPs), as SCPs can point to an elevated risk of adverse outcomes later in life, and more research is needed in this area (Gutman, Joshi, Khan, \& Schoon, 2018). Fourth, it remains somewhat uncertain how various individual and family factors contribute to the longitudinal associations between childhood conduct problems and negative adolescent outcomes. Milkman and Wanberg (2012) state that "owing to the unique confluence of biological, psychological, and social forces, adolescence is often a stressful period of life." Apart from childhood conduct problems, individual and family factors have been found to be associated with negative adolescent outcomes like substance abuse and delinquent activities (Milkman \& Wanberg, 2012).

Using a population-based sample, this study aimed at examining the relationship between children with conduct problems and several negative outcomes in adolescence while controlling for a series of sociodemographic factors, family characteristics and adolescent experiences that have been found to be associated with negative outcomes in adolescence and/or adulthood. Spec- 
ifically, we proposed to answer the following questions: (a) Are children with conduct problems before the age of 10 more likely to engage in physically violent offenses, non-violent offenses, deviant lifestyle, and/or consumption of tobacco, cannabis, or alcohol in adolescence? and (b) Are they more likely to meet the symptom count diagnostic criteria for CD in adolescence?

\section{Method}

\section{Participants}

Participants were 3,725 children aged 6-9 years in 1994-1995 in the National Longitudinal Survey of Youth and Children (NLSCY) Cycle 1 and their outcomes six years later (when they were 12-15 years old) in NLSCY Cycle 4 (2000-2001). We used data from the confidential NLSCY Master File in the New Brunswick Research Data Centre (RDC) in Canada.

Measures

Dependent Variables

A total of five binary variables capturing five groups of adolescent outcomes in Cycle 4 were selected as our dependent variables for this study. The original survey questions and variables used in the NLSCY to define the first four dependent variables are provided in Appendix A.

(1) Physically violent offenses. This variable was given a value of 1 if an adolescent reported causing physical injuries, mugging, fighting with a weapon, or sexual assault, 0 otherwise.

(2) Non-violent offenses. This variable was given a value of 1 if an adolescent reported stealing from outside (school or a store), breaking into a house or building, destroying others' property, or setting fire on purpose, 0 otherwise.

(3) Deviant lifestyle. This variable was given a value of 1 if an adolescent reported selling drugs, gang membership (being part of gang that broke law by stealing, hurting someone, damaging property etc.), or contact with police, 0 otherwise.

(4) Consumption of tobacco, cannabis, or alcohol. This variable was given a value of 1 if an adolescent reported smoking, consuming marijuana, or drinking alcohol, 0 otherwise.

(5) Conduct Disorder in Adolescence (CDA). The Current Symptom Scale (CSS) (Barkley and Murphy, 2006) was used to approximate symptom count diagnostic criteria for CD (Morse, Benson, \& Flory, 2015) based on self-completed behavioral items for 13 of the 15 DSM-5 CD symptoms in the last 12 months by adolescents aged 12-15 years in NLSCY Cycle 4 (see Appendix B). Two items ('has been physically cruel to animals' 
and 'is often truant from school') of the DSM-5 CD diagnosis were excluded because they were not available in the NLSCY. Based on the CSS scale, if an adolescent answered 'often or very true,' the response was considered as endorsing the symptom (Morse et al., 2015). Due to the severity of the symptom, 'I physically attack people' was coded positive even if reported as 'sometimes or somewhat true.' As a result, this symptom was more prevalent than other CD symptoms in our analysis (Lacourse et al., 2010). In the DSM-5, some serious CD behaviors (such as using a weapon, mugging, forcing someone into sexual activity, purposefully setting fire, breaking into a building or house, or damaging or destroying others' property) were considered to be clinically significant even if manifested only once in 12 months - such symptoms were coded positive (once or more $=1$; no=0) (Kim-Cohen et al., 2005; LA course et al., 2010). In Cycle 4, adolescents who endorsed three or more symptoms were categorized as meeting symptom count diagnostic criteria for CD based on the DSM- 5 (Morse et al., 2015) and this is our fifth dependent variable, Conduct Disorder in Adolescence (CDA).

Independent Variables

Childhood Conduct Problems (CCP) is the key independent variable for this study and was defined as follows. Children aged 6-9 in NLSCY Cycle 1 were identified as having CPP if they exhibited one or more DSM-5 CD symptom, such as physically attacks people; gets into many fights; cruel, bullies, or is mean to others; threatens people; kicks, bites, or hits other children; destroys his/her own things; destroys things belonging to others; vandalizes; tells lies or cheats; steals at home; or steals outside the home. A child was considered to have exhibited a symptom if he or she reported it as being 'very true or often true' (Lacourse et al., 2010). Due to the severity of the symptom, 'physically attacks people' was coded positive even if 'sometimes or somewhat true' was reported (Lacourse et al., 2010).

\section{Other Independent Variables}

To measure the extent to which associations between childhood conduct problems and conduct problems/negative outcomes in adolescence were explained by the effects of social, family, and related factors, the following three groups of measures were chosen from the NLSCY as additional independent variables in our analysis. These measures were chosen on the basis of previous literature as factors known to be associated with $\mathrm{CD}$ in children and adolescence (Fergusson \& Lynskey, 1998; McCabe, Hough, Wood, \& Yeh, 2001; Moffitt, Caspi, Harrington \& Milne, 2002). 
Sociodemographic Variables

(1) Gender.

(2) Ethnicity of the Adolescent. Ethnicity was categorized into 6 groups: Caucasian, Latin American, Asian, Black, Aboriginal, and Arab.

(3) Low Income Adequacy. This variable was dichotomized by combining the lowest and lower income adequacy categories to indicate (1=low income adequacy), while the middle, upper middle, and highest income adequacy groups were combined to indicate $(0=$ high income adequacy), a dichotomous grouping that closely corresponds to Canada's Low Income Cut-Off (LICO) (Charach, Cao, Schachar, \& To, 2006).

(4) Single Parent Household. An adolescent who lived with a single parent or was an orphan in Cycle 4 was categorized as 1, 0 otherwise. It must be noted that individuals who were orphans comprised only $0.6 \%$ of the total sample, and they were combined with single parent households so as not to exclude them from the analysis.

(5) Mother's Low Education. Maternal education level was categorized as $1=$ those with less than high school and $0=$ those with more than high school (Charach et al., 2006).

(6) Mother's age group at childbirth. This variable was directly measurable from the survey data, which contained five age groups - 13-24, 25-29, 30-34, 35-39, and 40+with 13-24 being the reference group.

(7) Rural/Urban. This variable was directly measurable from the survey data.

\section{Family Characteristics}

(1) Family Dysfunction. This was measured as a dichotomous variable; a family with a score of 15 or above was considered a dysfunctional family and coded 1, 0 otherwise (l'Institut de la statistique du Québec, 2000).

(2) Maternal Depression. This was measured as a dichotomous variable; Person Most Knowledgeable (PMKs) who scored 9 or above were coded 1 (depressed), and PMKs who scored 8 or less were coded 0 (not depressed) (Somers \& Willms, 2002).

(3) Parental Alcohol Use. The variable was coded 1 if the frequency of alcohol consumption for either parent was more than once monthly, 0 otherwise (Charach et al., 2006). 
(4) Parental Smoking. For either parent, this variable was recorded as present or absent in response to the question, "At the present time do/does you/he/she smoke cigarettes daily, occasionally or not at all?" (Charach et al., 2006).

(5) Exposure to Violence at Home. This variable was determined in response to the questions, "How often does your child see adults in your house physically fighting, hitting or otherwise trying to hurt others?" (Hotton, 2003) and "How often does your child watch television shows or movies that have a lot of violence in them?" If the individual answered "often" to either of these questions, the variable was coded 1, 0 otherwise.

\section{Adolescent Experiences}

(1) Yelling at Adolescent. This variable was measured as 1 if adolescents were 'often' or 'always' yelled at and 0 if adolescents were 'never' or 'sometimes' yelled at.

(2) Abuse of Adolescent. An adolescent who reported abuse was categorized as a dichotomous variable ( 1 , yes or 0 , no).

(3) Physical Punishment. This variable was categorized as 1 if adolescents were 'often' or 'always' punished and 0 if adolescents were 'never' or 'sometimes' punished.

(4) Conflict between Parents. This variable was coded 1 if the adolescent experienced conflict between parents, 0 otherwise.

(5) Attention-Deficit Hyperactivity Disorder (ADHD). An adolescent was coded 1 for ADHD if he/she received a NLSCY's Hyperactivity/Inattention score of 9 or above (Willms, 2002; Currie \& Stabile, 2003).

\section{Procedure}

The collection of data for NLSCY Cycle 1 began in 1994-1995, with follow-up surveys occurring every two years until Cycle 8 in 2008-2009, which was the last cycle. The NLSCY used a cluster sample of private households in the 10 Canadian provinces but excluded children living in institutions and living on reserves or remote areas (NLSCY Cycle 1, 1994-1995). For this study, we selected participants (6-9 years old) who had responses from the PMK on one or more conduct problem in Cycle 1 and self-reported outcomes in adolescence (12-15 years) in Cycle 4 . We selected Cycle 4 because it contained the highest number of questions on conduct problems and negative outcomes for our desired longitudinal sample when compared to later cycles, which had very few questions on conduct problems. For instance, in Cycle 8, most of the questions on conduct problems were asked only to youths aged 14-15 who had been 0-1 years old in Cycle 1 and thus were too young to be included in our sample. We used self-reported measures in Cycle 4, as the 
strategy of the NLSCY was to cease asking the same questions on conduct problems to PMKs typically parents - after children reached age 12 (Curtis, Dooley, \& Phipps, 2000). All analyses were conducted using the longitudinal survey weights provided by Statistics Canada to take account of attrition, non-response, and stratified sampling design (Lacourse et al., 2010).

\section{Data Analyses}

Both descriptive statistics and logistic regressions were used to explore the association between childhood conduct problems and each of the five binary dependent variables while controlling for our independent variables. The independent variables were added to logistic regressions in two sets. The first set (Model 1) included only the sociodemographic variables as controls. For robustness checks, the second set (Model 2) included all three groups of independent variables as controls. The software STATA (Version 14) was used for all regression analyses.

\section{Results}

Our longitudinal sample was evenly divided across the genders (51\% boys \& $49 \%$ girls), and more than $90 \%$ were Caucasians (Lacourse et al., 2010). More than $80 \%$ lived with both parents (Table 1 for a description of the characteristics of the sample). In our sample of 3,725 children a total of $22.2 \%$ of the adolescents aged 12-15 years in Cycle 4 engaged in one or more conduct problems when they were 6-9 years old in Cycle 1. Out of this $22.20 \%$ around $15.07 \%$ exhibited one symptom; $4.36 \%$ exhibited two symptoms; and $2.77 \%$ exhibited three or more symptoms. Around $77.80 \%$ exhibited no DSM-5 CD symptoms and thus, most of the participants in our sample had no symptoms $(77.8 \%)$ or were considered subclinical cases (i.e., exhibiting one or two symptoms, 19.43\%). Most children came from families with middle/high income adequacy (94.3\%). Figures 1.1(a) and 1.1(b) showed that individuals who had one or more childhood conduct problem in NLSCY Cycle 1 had a higher prevalence rate of all the Physically violent and Non-violent offenses except for mugging in Cycle 4 than individuals without childhood conduct problems in Cycle 1. The prevalence rates of CD symptoms such as physically attacking others; stealing from outside (store or school); reacting with anger and fighting; kicking, biting, and hitting; and setting fire on purpose were more than double for adolescents with childhood conduct problems when compared to adolescents who did not have them. Similarly, individuals with childhood conduct problems had a higher prevalence of deviant and negative outcomes in adolescence when compared to children without childhood conduct problems. The prevalence was higher especially for selling drugs; buying drugs; smoking; gang membership; and contact with police.

Our main results were summarized in Table 2, which showed the association between our key independent variable, childhood conduct problems (CCP), and the five dependent variables: Physically violent offenses; Non-violent offenses; Deviant lifestyle; Consumption of tobacco, cannabis, or alcohol; and CD in adolescence. The estimated coefficients in Table 2 (with Model 1 controlling for the sociodemographic variables only and Model 2 controlling for all independent variables) are the odds ratios indicating the strength of any positive or negative correlation between 
$\mathrm{CCP}$ and each of the five dependent variables. The results in this table came directly from our logistic regressions between each of the five dependent variables and $\mathrm{CCP}$ while controlling for the sociodemographic variables only (Appendix C, Model 1) and for all independent variables (Appendix D, Model 2).

First, with only the sociodemographic variables included (second row of Table 2), CCP was found to be significantly associated with the Non-violent offenses variable $(\mathrm{p}<.01)$ : children who displayed one or more CD symptom under the age of 10 were 1.63 times more likely to commit Non-violent offenses in adolescence. Even after controlling for all independent variables (third row of Table 2), the likelihood remained significant. The results from Model 1 (second row of Table 2) also show that consumption of tobacco, cannabis, or alcohol was found to be significantly associated with $\mathrm{CCP}(\mathrm{p}<.05)$ : children with one or more $\mathrm{CD}$ symptom were 1.42 times more likely to smoke, drink, or consume marijuana, even after controlling for sociodemographic variables. Our results from Model 1 also reveal that CCP was significantly associated with meeting the symptom count diagnostic criteria for $\mathrm{CD}$ in adolescence at $(\mathrm{p}<.05)$ : children with one or more CD symptom were 1.37 times more likely have a diagnosis of $\mathrm{CD}$ in adolescence, even while controlling for sociodemographic variables. However, this result was not found to be significantly associated with Physically violent offenses and Deviant lifestyle in adolescence.

\section{Discussion}

The current study tested the hypothesis that children with childhood conduct problems symptoms and/or subclinical conduct problems on later outcomes (before 10 years) were likely to have negative outcomes in adolescence. The presented analyses confirmed and extended previous findings on the impact of childhood conduct problems on later outcomes. Controlling for adolescent age and other relevant sociodemographic factors such as low income, logistic regression analyses revealed that in the full longitudinal sample of 3,725 adolescents in NLSCY Cycle 4, children who engaged in one or more conduct problems when 6-9 years old were more likely to engage in non-violent offenses (stealing from school or a store, breaking into a house or building, destroying others' property, or setting a fire on purpose) six years later during their adolescence (12-15 years old). They were also more likely to meet the symptom count diagnostic criteria for CD in adolescence and were more likely to consume tobacco, cannabis, or alcohol.

The strength of this study came from our use of longitudinal data, which allowed us to test the hypothesis that individuals with childhood conduct problems (mostly with subclinical conduct problems) showed persisting antisocial behavior in adolescence. Interestingly, our results indicated that individuals with childhood conduct problems were more likely to engage in non-violent offenses in adolescence. This finding was supported by a study which after adjusting for parental socioeconomic status found that conduct problems in childhood were associated with adverse outcomes in adolescence including non-violent criminality (Lichtenstein et al., 2020).

In addition, after controlling for sociodemographic factors, childhood conduct problems were found to be associated with the consumption of tobacco, cannabis, or alcohol in adolescence. This finding had substantial support, as several prospective studies have strongly shown that conduct problems often precede the development of substance abuse problems like alcohol or drugs (Disney, Elkins, McGue, \& Iacono, 1999, Lichtenstein et al., 2020). A study examining the 
association between early conduct problems and early marijuana use before age 15 found that early conduct problems were linked to early marijuana use (Falls et al., 2011). This aligns with our findings; however, after accounting for two additional groups of independent variables (family characteristics and adolescent experiences) in our analysis, this variable ceased to be significant in our study. It should be mentioned that Falls et al. (2011) controlled only for sociodemographic variables in their study and did not control for highly endogenous family behavioral variables, which we did.

Our study revealed that after controlling for sociodemographic factors, childhood conduct problems were found to be associated with meeting the symptom count diagnostic criteria for CD in adolescence. This finding was supported by a research study which found that childhood conduct problems were correlated with adolescent conduct problems (Herrenkohl et al., 2010). However, after controlling for family behavioral variables, this association ceased to be significant. Thus, we found only partial support for the positive association between childhood conduct problems and $\mathrm{CD}$ in adolescence.

Our results did not show a statistically significant association between childhood conduct problems and physically violent offenses and deviant lifestyle in adolescence. However, individuals with childhood conduct problems except for mugging had a higher prevalence rates for all other physically violent symptoms (causing physical injuries, fighting with a weapon and sexual assault) and all of the deviant outcomes (selling drugs, gang membership, or contact with police) when compared to individuals who did not have childhood conduct problems.

\section{Limitations}

Our study had several limitations. For one, we conducted a longitudinal analysis of children aged 6-9 years old in NLSCY Cycle 1 who displayed one or more DSM-5 CD symptom and then assessed them six years later during their adolescence (aged 12-15 years) in NLSCY Cycle 4. When the children were 6-9 years old, responses to questions on CD symptoms were provided by the parents or other Persons Most Knowledgeable of the children; however, when the children became adolescents, they answered for themselves. Thus, our analysis was conducted using selfreported items of conduct problems in adolescence and parent-reported childhood conduct problems in Cycle 1. This could be a drawback to our study, as research has found that parent- and child-reported measures of psychopathology are not consistent, and, in the absence of any clinical in-depth psychiatric assessment, there remains the possibility of misclassification errors (Constant et al., 2014). However, many studies have found self-reported data from children and young adults to be valid, and the self-reported nature of the present study could be viewed as a strength (Morse et al., 2015).

As another weakness, we did not categorize the children with conduct problems as aggressive or violent (e.g., physically attacking people) and non-aggressive (e.g., stealing) and did not test the prognosis of these two groups separately in adolescence, as aggressive and nonaggressive symptoms differ in regard to etiology, severity, and progression. Future research using the NLSCY should divide childhood conduct problems under these two categories and examine their outcomes in adolescence. Further, the use of binary variables can limit the sensitivity of data. In terms of the data itself, while the NLSCY has a relatively reasonable degree of attrition, it is 
still possible that attrition biases our results in some manner. This study was also limited due to the lack of racial and ethnic diversity in the sample, as $91 \%$ of the sample was Caucasian.

\section{Conclusion}

Our findings reveal that individuals aged 6-9 years old who engaged in one or more conduct problems, were more likely to engage in non-violent offenses (stealing from school or a store, or to have broken into others house or building, or to have destroyed others property, or to have set fire on purpose) six years later during their adolescence (12-15 years). They were also likely to meet the symptom count diagnostic criteria for $\mathrm{CD}$ in adolescence and were also more likely to consume tobacco, cannabis, or alcohol. However, the hypothesis that individuals with early onset of $\mathrm{CD}$ were more likely to commit offenses involving violence (to have sexually assaulted someone, or to have used a weapon, or to have stolen with confrontation) and were also likely have deviant lifestyle outcomes in adolescence was not supported. 


\section{References}

American Psychiatric Association. (2013). Diagnostic and statistical manual of mental disorders (DSM). (5th Edn) Washington, DC: American Psychiatric Association.

Barkley, R.A., Murphy, K.R. (2006). Attention-Deficit Hyperactivity Disorder: A Clinical Workbook. 3rd ed. New York, NY: Guilford Press.

Conduct Problems Prevention Research Group. (2010). The Fast Track Project: Preventing severe conduct problems in school-age youth. In R. C. Murrihy et al. (Eds.), Clinical handbook of assessing and treating conduct problems in youth (pp. 407-433). New York, NY: Springer. https://doi.org/10.1007/978-1-4419-6297-3_16

Charach, A., Cao, H., Schachar, R., \& To, T. (2006). Correlates of methylphenidate use in Canadian children: A cross-sectional study. The Canadian Journal of Psychiatry, 51(1), 17-26. https://doi.org/10.1177/070674370605100105

Constant, A., Dulioust, J., Wazana, A., Shojaei, T., Pitrou, I., \& Kovess-Masfety, V. (2014). Utility of self-reported mental health measures for preventing unintentional injury: results from a cross-sectional study among French schoolchildren. BMC Pediatrics, 14, 2. https://doi.org/10.1186/1471-2431-14-2

Copeland, W. E., Wolke, D., Shanahan, L., \& Costello, E. J. (2015). Adult functional outcomes of common childhood psychiatric problems. JAMA Psychiatry, 72(9), 892. https://doi.org/10.1001/jamapsychiatry.2015.0730

Currie, J., \& Stabile, M. (2003). Socioeconomic status and child health: Why is the relationship stronger for older children? American Economic Review, 93(5), 1813-1823. https://doi.org/10.1257/000282803322655563

Curtis, L., Dooley, M., \& Phipps, S. (2002). Does parent or child know best? An assessment of parent/child agreement in the Canadian National Longitudinal Survey of Children and Youth. Retrieved from https://www150.statcan.gc.ca/n1/en/pub/11f0019m/11f0019m2002181-eng.pdf?st=ZfOW9JX

De Sanctis, V. A., Nomura, Y., Newcorn, J. H., \& Halperin, J. M. (2012). Childhood maltreatment and conduct disorder: Independent predictors of criminal outcomes in ADHD youth. Child Abuse \& Neglect, 36(11-12), 782-789. https://doi.org/10.1016/j.chiabu.2012.08.003

Disney, E. R., Elkins, I. J., McGue, M., \& Iacono, W. G. (1999). Effects of ADHD, Conduct Disorder, and gender on substance use and abuse in adolescence. American Journal of Psychiatry, 156(10), 1515-1521. https://doi.org/10.1176/ajp.156.10.1515

Escarce, J. J. (2003). Socioeconomic status and the fates of adolescents. Health Services Research, 38(5), 1229-1234. https://doi.org/10.1111/1475-6773.00173

Falls, B. J., Wish, E. D., Garnier, L. M., Caldeira, K. M., O’Grady, K. E., Vincent, K. B., \& Arria, A. M. (2011). The association between early conduct problems and early marijuana use in college students. Journal of Child \& Adolescent Substance Abuse, 20(3), 221-236. https://doi.org/10.1080/1067828x.2011.581900

Fergusson, D. M., \& Lynskey, M. T. (1998). Conduct problems in childhood and psychosocial outcomes in young adulthood. Journal of Emotional and Behavioral Disorders, 6(1), 218. https://doi.org/10.1177/106342669800600101 
Frick, P. J. (2016). Current research on conduct disorder in children and adolescents. South African Journal of Psychology, 46(2), 160-174. https://doi.org/10.1177/0081246316628455

Furlong, M., McGilloway, S., Bywater, T., Hutchings, J., Smith, S. M., \& Donnelly, M. (2012). Behavioural and cognitive-behavioural group-based parenting programmes for earlyonset conduct problems in children aged 3 to 12 years. Cochrane Database of Systematic Reviews. https://doi.org/10.1002/14651858.cd008225.pub2

Goldstein, R. B., Grant, B. F., Ruan, W. J., Smith, S. M., \& Saha, T. D. (2006). Antisocial Personality Disorder with childhood- vs adolescence-onset Conduct Disorder. The Journal of Nervous and Mental Disease, 194(9), 667-675. https://doi.org/10.1097/01.nmd.0000235762.82264.a1

Gutman, L., Joshi, H., Khan, L., \& Schoon, I. (2018). Children of the millennium: Understanding the course of conduct problems during childhood [PDF file]. Retrieved from https://www.centreformentalhealth.org.uk/sites/default/files/201811/Children\%20of\%20the\%20Millennium.pdf

Herrenkohl T. I., Kosterman R., Mason W. A., Hawkins J. D., McCarty C. A., McCauley E. (2010). Effects of childhood conduct problems and family adversity on health, health behaviors, and service use in early adulthood: tests of developmental pathways involving adolescent risk taking and depression. Dev. Psychopathol. 22 655-665. https://doi.org/10.1017/S0954579410000349

Hotton, T. (2003). Childhood aggression and exposure to violence in the home. Crime and Justice Research Paper Series, Statistics Canada. Catalogue No. 85-561-MWE2003002

l'Institut de la statistique du Québec. (2000). Longitudinal study of child development in Québec (ÉLDEQ 1998-2002) [PDF file]. Retrieved from http://www.jesuisjeserai.stat.gouv.qc.ca/publications/baby_n10.pdf

Johnson, V. A., Kemp, A. H., Heard, R., Lennings, C. J., \& Hickie, I. B. (2015). Childhoodversus adolescent-onset Antisocial Youth with Conduct Disorder: Psychiatric illness, neuropsychological and psychosocial function. PLOS ONE, 10(4), e0121627. https://doi.org/10.1371/journal.pone.0121627

Kassing, F., Godwin, J., Lochman, J. E., \& Coie, J. D. (2018). Using early childhood behavior problems to predict adult convictions. Journal of Abnormal Child Psychology, 47(5), 765-778. https://doi.org/10.1007/s10802-018-0478-7

Lacourse, E., Baillargeon, R., Dupéré, V., Vitaro, F., Romano, E., \& Tremblay, R. (2010). Twoyear predictive validity of conduct disorder subtypes in early adolescence: A latent class analysis of a Canadian longitudinal sample. Journal of Child Psychology and Psychiatry, 51(12), 1386-1394. https://doi.org/10.1111/j.1469-7610.2010.02291.x

Lahey, B. B., Goodman, S. H., Waldman, I. D., Bird, H., Canino, G., Jensen, P., ... Applegate, B. (1999). Relation of age of onset to the type and severity of child and adolescent conduct problems. Journal of Abnormal Child Psychology, 27(4), 247-260. https://doi.org/10.1023/a:1022661224769

Lahey, B. B., Loeber, R., Burke, J., \& Rathouz, P. J. (2002). Adolescent outcomes of childhood Conduct Disorder among clinic-referred boys: Predictors of improvement. Journal of Abnormal Child Psychology, 30(4), 333-348. https://doi.org/10.1023/a:1015761723226 
Lichtenstein, P., Cederlöf, M., Lundström, S., D'Onofrio, B. M., Anckarsäter, H., Larsson, H., \& Pettersson, E. (2020). Associations between conduct problems in childhood and adverse outcomes in emerging adulthood: a longitudinal Swedish nationwide twin cohort. Journal of child psychology and psychiatry, and allied disciplines, 61(7), 798-806. https://doi.org/10.1111/jcpp.13169

Loeber, R., Wei, E., Stouthamer-Loeber, M., Huizinga, D., \& Thornberry, T.P. (1999). Behavioral antecedents to serious and violent offending: Joint analyses from the Denver Youth Survey, Pittsburgh Youth Study and the Rochester Youth Development Study. Studies on Crime and Crime Prevention, 8, 245-263.

Loeber, R., Farrington D.P. (2001) The significance of child delinquency. In: Loeber R, Farrington DP, editors. Child delinquents. Thousand Oaks, CA: Sage, 1-22.

López-Romero, L., Romero, E., \& Andershed, H. (2014). Conduct problems in childhood and adolescence: Developmental trajectories, predictors and outcomes in a six-year follow up. Child Psychiatry \& Human Development, 46(5), 762-773. https://doi.org/10.1007/s10578-014-0518-7

McCabe, K. M., Hough, R., Wood, P. A., \& Yeh, M. (2001). Childhood and adolescent onset Conduct Disorder: A test of the developmental taxonomy. Journal of Abnormal Child Psychology, 29(4), 305-316. https://doi.org/10.1023/a:1010357812278

Milkman, H. B., \& Wanberg, K. W. (2012). Criminal conduct and substance abuse treatment for adolescents: Pathways to self-discovery and change: The provider's guide. Thousand Oaks: SAGE.

Moffitt, T. E. (1993). Adolescence-limited and life-course-persistent antisocial behavior: A developmental taxonomy. Psychological Review, 100(4), 674-701. https://doi.org/10.1037/0033-295x.100.4.674

Moffitt, T., E, Caspi, A., Harrington, H., \& Milne, B. (2002). Males on the life-course-persistent and adolescence-limited antisocial pathways: Follow-up at age 26 years. Development and Psychopathology, 14(1), 179-207. https://doi.org/10.1017/s0954579402001104

Morse, M. C., Benson, K., \& Flory, K. (2015). Disruptive behavior disorders and marijuana use: The role of depressive symptoms. Substance Abuse: Research and Treatment, 9 (Suppl 1), 69-76. https://doi.org/10.4137/SART.S31432

National Academies of Sciences, Engineering, and Medicine National Academies of Science [NASEM]. (2015). Mental disorders and disabilities among low-income children. Washington, DC: The National Academies Press. https://doi.org/10.17226/21780

Odgers, C. L., Caspi, A., Broadbent, J. M., Dickson, N., Hancox, R. J., Harrington, H., ... Moffitt, T. E. (2007). Prediction of differential adult health burden by conduct problem subtypes in males. Archives of General Psychiatry, 64(4), 476. https://doi.org/10.1001/archpsyc.64.4.476

Patterson, G. R., Capaldi, D., \& Bank, L. (1991). An early starter model for predicting delinquency. In D. J. Pepler \& K. H. Rubin (Eds.), The development and treatment of childhood aggression (pp. 139-168). Hillsdale, NJ: Lawrence Erlbaum Associates, Inc.

Somers, M. A., Willms, J. D. (2002) Maternal depression and childhood vulnerability. In J. D. Willms (Ed.), Vulnerable Children: Findings from Canada's national longitudinal survey of children and youth (pp. 211-228). Edmonton, AB: University of Alberta Press and Human Resources. 
Waldman, I. D., \& Lahey, B. B. (2010). Oppositional Defiant Disorder, Conduct Disorder, and juvenile delinquency. In T. P. Beauchaine \& S. P. Hinshaw (Eds.), Child and adolescent psychopathology (2nd ed., pp. 411-438). Hoboken, NJ: Wiley.

Walters, G. D. (2014). Forging a link between Conduct Disorder and adolescent/adult offending via externalizing behavior and reading performance. Youth Violence and Juvenile Justice, 14(1), 61-75. https://doi.org/10.1177/1541204014551427

Willms, J. D. (Ed.). (2002). Vulnerable Children. Edmonton, AB: University of Alberta Press. 


\section{Table 1}

Characteristics of the Longitudinal Sample, $n=3,725$

Characteristics $\%$

Gender

Total (in \%)

Girls

$48.8 \%$

Boys

$51.2 \%$

Ethnicity

Caucasian $\quad 90.8 \%$

Asian $\quad 4.9 \%$

Black $\quad 1.7 \%$

Aboriginal $2.0 \%$

Arab $\quad 0.3 \%$

Latin American $\quad 0.4 \%$

Single parent household

Lives with two parents $\quad 80.1 \%$

Lives with one parent only $\quad 19.0 \%$

Does not live with a parent $\quad 0.63 \%$

Mother's age group
$13-24$
$25.6 \%$
25-29
$38.1 \%$
30-34
$26.2 \%$
35-39
$9.3 \%$
$40+$
$0.6 \%$

Mothers low education

Education higher than high school $\quad 87.4 \%$

Education less than high school $12.5 \%$

Low income adequacy

Middle/high income adequacy $\quad 94.3 \%$

Lowest/low income adequacy $\quad 5.6 \%$ 
Table 2

Summary Regression Results:

Association between Childhood Conduct Problems and Negative Adolescent Outcomes

\begin{tabular}{llllll}
\hline & $\begin{array}{l}\text { Physical } \\
\text { Violence }\end{array}$ & $\begin{array}{l}\text { Non- } \\
\text { Violent } \\
\text { Offenses }\end{array}$ & $\begin{array}{l}\text { Deviant } \\
\text { Outcomes }\end{array}$ & $\begin{array}{l}\text { Consumption } \\
\text { of Tobacco, } \\
\text { Cannabis, or } \\
\text { Alcohol }\end{array}$ & $\begin{array}{l}\text { CD in } \\
\text { Adolescence }\end{array}$ \\
\hline Model 1* & 1.17 & $1.63^{* * *}$ & 1.19 & $1.42^{* *}$ & $1.37^{* *}$ \\
Model 2* & 1.04 & $1.48^{* * *}$ & 1.02 & 1.15 & 1.10 \\
\hline
\end{tabular}

*** Significance at the $1 \%$ level

**Significance at the $5 \%$ level

*Model 1 included only the sociodemographic variables as controls.

*Model 2 included all three groups of independent variables as controls. 
Appendix A

\begin{tabular}{llll}
\hline $\begin{array}{l}\text { Measures of Adolescence } \\
\text { Outcomes (12-15 years) }\end{array}$ & Offense/Outcome & $\begin{array}{l}\text { NLSCY Cycle 4 Self-Completed } \\
\text { Survey Questions }\end{array}$ & $\begin{array}{l}\text { NLSCY } \\
\text { Variable }\end{array}$ \\
\hline
\end{tabular}

Physically Violent

Offenses:

Caused physical injuries

Mugging

Fighting with a

Weapon

Sexual assault
About how many times have you fought

DFBCbQ2P with someone to the point where they needed care for their injuries (for example, because they were bleeding, or had broken bones?)

During the past 12 months, about how many times have you threatened someone in order to get their money or things?

During the past 12 months, about how many times have you been in a fight where you hit someone with something other than your hands (for example, a stick, club, knife, or rock)?

During the past 12 months, about how many times have you attempted to touch the private parts of another person's body knowing that they would probably object to this?

During the past 12 months, about how many times have you tried to force someone into having sex with you?

DFBCb2BB
DFBCbQ2V

DFBCbQ2Q

DFBCb2AA

During the past 12 months, about how

DFBCcQ2H

Stealing from many times have you stolen something from a store or school?

Broken into others house or building

DFBCbQ2K
During the past 12 months, about how many times have you broken into, or snuck into, a house or building with the idea of stealing something? 
Destroyed others property

Setting fire on Purpose
About how many times have you damaged or destroyed anything that didn't belong to you (for example, damaged a bicycle, car, school furniture, broken windows or written graffiti)?

During the past 12 months, about how

DFBCb2EE many times have you set fire on purpose to a building, a car, or something else not belonging to you?

Deviant Life Style:

Sold drugs

Gang membership

police

Contact with the

\section{During the past 12 months, have you sold any drugs?}

During the past 12 months, were you part of a gang that broke the law, by stealing, hurting someone, damaging property, etc.? During the past 12 months, were you questioned by the police about anything that they thought you did? 


\section{Appendix B}

\section{DSM-5 Conduct Disorder (Dependent Variable) and NLSCY Cycle 4 variables (12-15 years)}

\begin{tabular}{|c|c|c|}
\hline DSM-5 Conduct Disorder & Comparable NLSCY CD Symptoms & $\begin{array}{l}\text { NLSCY } \\
\text { Variable }\end{array}$ \\
\hline \multicolumn{3}{|l|}{$\begin{array}{l}\text { I. Aggression to People and } \\
\text { Animals }\end{array}$} \\
\hline \multirow{2}{*}{$\begin{array}{l}\text { Often bullies, threatens, or } \\
\text { intimidates others. }\end{array}$} & I threaten people. & DFBCQ1FF \\
\hline & I bully or am mean to others. & DFBCQ1JJ \\
\hline \multirow[t]{2}{*}{ Often initiates physical fights } & I get into many fights. & DFBCQ01G \\
\hline & $\begin{array}{l}\text { When another kid accidentally hurts me, I } \\
\text { assume that he/she meant to do it, and I react } \\
\text { with anger and fighting. }\end{array}$ & DFBCd01X \\
\hline $\begin{array}{l}\text { Has used a weapon that can cause } \\
\text { serious physical harm to others } \\
\text { (e.g., a bat, brick, broken bottle, } \\
\text { knife, gun). }\end{array}$ & $\begin{array}{l}\text { During the past } 12 \text { months, about how many } \\
\text { times have you been in a fight where you hit } \\
\text { someone with something other than your } \\
\text { hands (for example, a stick, club, knife, or } \\
\text { rock)? }\end{array}$ & DFBCd01X \\
\hline \multirow{2}{*}{$\begin{array}{l}\text { Has been physically cruel to } \\
\text { people. }\end{array}$} & I physically attack people. & DFBCQ1AA \\
\hline & I kick or hit other people my age. & DFBCQ1NN \\
\hline $\begin{array}{l}\text { Has stolen while confronting a } \\
\text { victim. }\end{array}$ & $\begin{array}{l}\text { During the past } 12 \text { months, about how many } \\
\text { times have you threatened someone in order } \\
\text { to get their money or things? }\end{array}$ & DFBCbQ2V \\
\hline \multirow[t]{2}{*}{$\begin{array}{l}\text { Has forced someone into sexual } \\
\text { activity. }\end{array}$} & $\begin{array}{l}\text { During the past } 12 \text { months, about how many } \\
\text { times have you attempted to touch the } \\
\text { private parts of another person's body } \\
\text { knowing that they would probably object to } \\
\text { this? }\end{array}$ & $\mathrm{DFBCb} 2 \mathrm{AA}$ \\
\hline & $\begin{array}{l}\text { During the past } 12 \text { months, about how many } \\
\text { times have you tried to force someone into } \\
\text { having sex with you? }\end{array}$ & $\mathrm{DFBCb} 2 \mathrm{BB}$ \\
\hline
\end{tabular}

II. Destruction of Property

Has deliberately engaged in fire During the past 12 months, about how many DFBCb2EE setting. 
building, a car, or something else not

belonging to you?

Has deliberately destroyed others' property (other than by fire setting)

I destroy things belonging to my family or other young people/ I destroy my own things.

About how many times have you damaged or destroyed anything that didn't belong to you (for example, damaged a bicycle, car, school furniture, broken windows or written graffiti)?

I vandalize.
DFBCQ01L/

DFBCQ01C

DFBCbQ2O

DFBCQ1DD
III. Deceitfulness or Theft

Has broken into someone else's house, building, or car.

Often lies or cons.

Has stolen items of nontrivial value without confronting a victim.
During the past 12 months, about how many

DFBCbQ2K times have you broken into, or snuck into, a house or building with the idea of stealing something?

I tell lies or cheat.

DFBCQ01T

I steal at home. DFBCQ01E

I steal outside my home.

DFBCQ1PP
IV. Serious Violations of Rules

Often stays out at night despite parental prohibitions.

Has run away from home overnight at least twice.
During the past 12 months, about how many

DFBCbQ2B times have you stayed out all night without permission?

During the past 12 months, about how many times have you run away from home?
DFBCbQ2F 


\section{Appendix C}

Model 1: Logistic Regression of Childhood Conduct Problems (Cycle 1) and Conduct Problems in Adolescence (Cycle 4): Socioeconomic Variables (Odds Ratio)

\begin{tabular}{|c|c|c|c|c|c|}
\hline & $\begin{array}{l}\text { Physically } \\
\text { Violent } \\
\text { Offenses }\end{array}$ & $\begin{array}{l}\text { Non-Violent } \\
\text { Offenses }\end{array}$ & $\begin{array}{l}\text { Deviant } \\
\text { Lifestyle }\end{array}$ & $\begin{array}{l}\text { Consumption } \\
\text { of Tobacco, } \\
\text { Cannabis, or } \\
\text { Alcohol }\end{array}$ & CD in Cycle 4 \\
\hline $\begin{array}{l}\text { Childhood Conduct } \\
\text { Problems }\end{array}$ & 1.17 & $1.63 * * *$ & 1.19 & $1.42 * *$ & $1.37 * *$ \\
\hline Male & $2.79 * * *$ & $1.37 * * *$ & $2.20 * * *$ & 0.91 & $2.19 * * *$ \\
\hline \multicolumn{6}{|l|}{$\begin{array}{l}\text { Adolescents' Age } \\
\text { (reference category } 12 \\
\text { years) }\end{array}$} \\
\hline 13 years & 1.34 & $1.86 * * *$ & $1.91 * * *$ & $5.29 * * *$ & $1.61 * * *$ \\
\hline 14 years & $1.70 * * *$ & $2.30 * * *$ & $2.66 * * *$ & $18.63 * * *$ & $2.44 * * *$ \\
\hline 15 years & $1.64 * * *$ & $2.81 * * *$ & $2.96 * * *$ & $27.06 * * *$ & $2.45 * * *$ \\
\hline Mother's Low Education & 1.19 & 1.08 & 1.13 & 1.04 & $1.46 * *$ \\
\hline Low Income Adequacy & $1.76^{* * *}$ & 1.09 & 1.14 & 0.99 & 1.00 \\
\hline Single Parents/ Orphans & 0.81 & $1.59 * * *$ & $1.39 * * *$ & $2.06 * * *$ & $1.37 * *$ \\
\hline \multicolumn{6}{|l|}{$\begin{array}{l}\text { Mother's Age Group } \\
\text { (reference age group 13- } \\
24 \text { ) }\end{array}$} \\
\hline $25-29$ & 0.94 & 0.87 & 0.92 & $0.62 * * *$ & 0.87 \\
\hline $30-34$ & 0.69 & 0.95 & 0.86 & $0.48 * * *$ & 0.83 \\
\hline $35-39$ & $0.37 * * *$ & 0.67 & $0.53 * *$ & $0.45 * * *$ & 0.63 \\
\hline $\begin{array}{l}\qquad 40+ \\
\text { Ethnicity (reference } \\
\text { ethnic group Caucasian) }\end{array}$ & 1.10 & 0.25 & 0.67 & 0.44 & 2.14 \\
\hline Asian & 0.41 & 0.46 & 0.52 & 0.18 & 0.26 \\
\hline Black & 1.62 & 1.13 & 1.99 & 1.00 & 0.85 \\
\hline Aboriginal & 1.73 & $1.80 * *$ & 1.73 & 1.54 & $2.27 * * *$ \\
\hline Arab & 0.99 & 0.51 & 1.43 & 1.00 & 1.00 \\
\hline Latin American & 3.81 & 3.37 & 1.86 & 1.49 & 3.36 \\
\hline
\end{tabular}

*** Significance at the $1 \%$ level

** Significance at the $5 \%$ level

Note: Regression controlled for provincial dummy variables 


\section{Appendix D}

Model 2: Logistic Regression of Childhood Conduct Problems (Cycle 1) and Conduct Problems in Adolescence (Cycle 4): All Independent Variables (Odds Ratio)

\begin{tabular}{llllll}
\hline & $\begin{array}{l}\text { Physically } \\
\text { Violent } \\
\text { Offenses }\end{array}$ & $\begin{array}{l}\text { Non-Violent } \\
\text { Offenses }\end{array}$ & $\begin{array}{l}\text { Deviant } \\
\text { Lifestyle }\end{array}$ & $\begin{array}{l}\text { Consumption of } \\
\text { Tobacco, } \\
\text { Cannabis, or } \\
\text { Alcohol }\end{array}$ & $\begin{array}{l}\text { CD } \\
\text { Diagnosis in } \\
\text { Cycle } 4\end{array}$ \\
\hline $\begin{array}{l}\text { Childhood } \\
\text { Conduct }\end{array}$ & 1.04 & $1.48^{* * *}$ & 1.02 & 1.15 & 1.10 \\
$\begin{array}{l}\text { Problems } \\
\text { Male }\end{array}$ & $3.01 * * *$ & $1.38^{* * *}$ & $2.27 * * *$ & 0.86 & $2.29 * * *$
\end{tabular}

Adolescents'

Age

(reference

category 12

years)

$\begin{array}{llllll}13 \text { years } & 1.33 & 1.81 * * * & 1.89 * * * & 5.13 * * * & 1.5 * * \\ 14 \text { years } & 1.67 * * * & 2.13 * * * & 2.51 * * * & 18.28 * * * & 2.21 * * * \\ 15 \text { years } & 1.60 * * * & 2.68 * * * & 2.85 * * * & 28.09 * * * & 2.24 * * *\end{array}$

Mother's Low

$1.13 \quad 1.03$

1.06

0.94

$1.46^{* *}$

Education

Low Income

$1.84 * * *$

1.16

1.20

1.04

1.08

Adequacy

Single

0.73

$1.47 * * *$

1.24

$1.76 * * *$

1.21

Parents/

Orphans

Mother's Age

Group

(reference age

group 13-24) 


$\begin{array}{clllll}25-29 & 0.98 & 0.89 & 0.96 & 0.65^{* * *} & 0.88 \\ 30-34 & 0.77 & 1.04 & 0.96 & 0.53^{* * *} & 0.91 \\ 35-39 & 0.42^{* * *} & 0.75 & 0.60 & 0.53 & 0.74 \\ 40+ & 1.16 & 0.26 & 0.73 & 0.54 & 2.37\end{array}$

Ethnicity

(reference

ethnic group

Caucasian)

(Reference)

\begin{tabular}{|c|c|c|c|c|c|}
\hline Asian & 0.45 & 0.50 & 0.55 & 0.22 & $0.26 *$ \\
\hline Black & 1.71 & 1.20 & 2.03 & 1.00 & 0.96 \\
\hline Aboriginal & 1.30 & 1.47 & 1.23 & 1.15 & 1.75 \\
\hline Arab & 1.03 & 0.53 & 1.62 & 1.00 & 1.00 \\
\hline $\begin{array}{c}\text { Latin } \\
\text { American }\end{array}$ & 5.14 & 4.10 & 1.93 & 1.44 & 3.14 \\
\hline $\begin{array}{l}\text { Exposure to } \\
\text { Violence in } \\
\text { Home }\end{array}$ & 0.96 & $1.31 * *$ & $1.42 * * *$ & $1.51 * * *$ & $1.56 * * *$ \\
\hline $\begin{array}{l}\text { Conflict } \\
\text { between } \\
\text { Parents }\end{array}$ & $4.46^{* * * *}$ & 1.58 & $3.48 * * *$ & 1.85 & $2.81 * *$ \\
\hline $\begin{array}{l}\text { Parental } \\
\text { Alcohol Use }\end{array}$ & 0.97 & 1.17 & 1.04 & 1.25 & 1.20 \\
\hline $\begin{array}{l}\text { Parental } \\
\text { Smoking }\end{array}$ & $1.45 * * *$ & $1.43 * * *$ & $1.48 * * *$ & $1.78 * * *$ & $1.40 * * *$ \\
\hline $\begin{array}{l}\text { Parents Hit } \\
\text { Adolescent }\end{array}$ & $2.07 * * *$ & 1.75 & 1.17 & 1.83 & $2.78 * * *$ \\
\hline $\begin{array}{l}\text { Parents Yell at } \\
\text { Adolescent }\end{array}$ & $2.73 * * *$ & $2.74 * * *$ & $3.40 * * *$ & $3.02 * * *$ & $3.52 * * *$ \\
\hline $\begin{array}{l}\text { Maternal } \\
\text { Depression }\end{array}$ & 0.86 & 0.90 & 1.01 & 1.27 & 1.10 \\
\hline
\end{tabular}


Swarna, Leonard and $\mathrm{Yu}$

$\begin{array}{llllll}\text { Dysfunctional } & 1.38 & 1.18 & 1.12 & 0.95 & 1.31\end{array}$

Family

Adolescent $\quad 0.34$

$\begin{array}{llll}1.58 & 1.25 & 2.30 & 1.18\end{array}$

Experienced

Abuse

$\begin{array}{llllll}\mathrm{ADHD} & 3.02 * * * & 4.03 * * * & 3.48 * * * & 2.75 * * * & 6.73 * * *\end{array}$

*** Significance at the $1 \%$ level

$* *$ Significance at the $5 \%$ level

Note: Regression controlled for provincial dummy variables 